Article

\title{
Examining the impact of demographic and socio- economic factors on the level of employee preparedness for a disaster caused by fires: A case study of Electrical power distribution in Serbia
}

\author{
Vladimir M. Cvetković ${ }^{12, *}$, Kristina Marković ${ }^{3}$, \\ 1 Faculty of Security Studies, University of Belgrade, Gospodara Vučića 50, 11040 Belgrade, Serbia; vmc@fb.bg.ac.rs \\ 2 International Institute for Disaster Research, Dimitrija Tucovića 121, Belgrade, Serbia. \\ 3 Scientific-Professional Society for Disaster Risk Management, Dimitrija Tucovića 121, Belgrade, Serbia; \\ krisbleka93@gmail.com. \\ * Correspondence: vmc@fb.bg.ac.rs;
}

\begin{abstract}
This paper presents the results of quantitative research regarding the examination of the levels of efficiency of the fire protection system and the training of employees in Electrical power distribution of Serbia for fire protection, ie the analysis of the manner of implementation of fire protection measures, and determining whether these measures are adequately applied. Following the subject set in this way, the aim of the research was set, and that is the scientific analysis of the manner of application of fire protection measures. The results of this research showed that the employees of Electro distribution Belgrade perceive the preparedness of their company highly positively and certain socio-demographic characteristics also affect certain attitudes, especially those related to the experience with fire, the knowledge of employees to react in case of fire, and the choice of the appropriate response, assessment of the readiness of the company and the employees themselves. It was found that knowledge of how to react in case of fire is influenced by gender and level of education; the choice of one of the methods of action in case of fire is influenced by gender; the assessment of the readiness of the employees themselves is influenced by the marital status; the desire of employees to participate in training to increase their preparedness for fires is influenced by gender. The results of the research can be used to improve the preparedness of employees in various organizations to respond to disasters caused by fires.
\end{abstract}

Keywords: disaster; fire; preparedness; respond; employee; demographic; socio-economic; factors.

\section{Introduction}

Fires have always been a serious source of endangering the safety of people and their property (Cvetković, 2017; Cvetković \& Gačić, 2017; Cvetković, Giulia, et al., 2018; Cvetkovic, 2019; Fridolf, Nilsson, \& Frantzich, 2013; Kozlowski, 2012; Kuligowski, 2013; Rafi, Wasiuddin, \& Siddiqui, 2012). The frequency of fires, huge material damages, and human casualties, impose the need for a comprehensive view of this problem and taking broad social action, more complete and effective measures, both in terms of preventive protection and in suppressing and preventing serious consequences (Hulida, Pasnak, Koval, \& Tryhuba, 2019; Kasereka et al., 2018; Ma \& Wu, 2020). One of the very important systems, in which fires represent a high source of danger, and above all due to the basic activity of that system, is the electricity distribution system. Due to its importance for the whole society, ie everyday life, the electric power system is called 
critical infrastructure. Precisely because of that, various measures and activities for its protection have been developed (Fitzgerald, 2004; Hasofer \& Thomas, 2006; Kobes, Helsloot, De Vries, \& Post, 2010; Mousavi, Bagchi, \& Kodur, 2008; Pat-Horenczyk et al., 2012).

In electricity distribution, fires can be a frequent source of endangerment, given the activity itself. Any interruption in the functioning of the electricity distribution system, even the one caused by fires, can have severe consequences for the daily functioning of the company. Therefore, it is necessary to take various measures and activities to protect it. To enable safe operation of the power system in emergencies caused by fires, and as indicated in the rich literature, it is necessary to take various measures, primarily related to the prevention and reduction of fire risk (Thomson, 2002; Hong-jun, Xiao-lu, 2011). In this way, the system prepares for an emergency caused by fire, prevents or reduces the possibility of such an emergency, and allows an efficient response if it occurs, or allows it to perform its basic function in all conditions.

Preparedness in principle implies design, planning, implementation, and testing of measures to reduce natural and technical-technological hazards (Aleksandrina, Budiarti, Yu, Pasha, \& Shaw, 2019; Cvetkovic \& Martinović, 2020; Jha, 2020; Kumiko \& Shaw, 2019; Mano \& Rapaport, 2019; Ocal, 2019; Olawuni, Olowoporoku, \& Daramola, 2020; Vibhas, Adu, Ruiyi, Anwaar, \& Rajib, 2019; Xuesong \& Kapucu, 2019). Disaster preparedness can be defined as a set of different activities undertaken to minimize human casualties and material damage but also as organizing and facilitating effective rescue, disaster relief and rehabilitation "(Cvetković, 2020; Brown, 1993). In essence, when implementing structural fire protection measures in electricity distribution facilities, the following principles should be taken into account: 1) high-voltage and low-voltage devices, compensators, batteries and oil-insulated equipment must be installed in separate rooms with a separate fire protection system; the same applies to distribution systems, transmission stations, public electricity supply, as well as control rooms; 2) distribution equipment must be provided with external pressure relief for shock wave deflection in case of failure; 3 ) walls and ceilings should be built according to the highest class of fire resistance; 4) only non-combustible materials may be used as construction materials; 5 ) access doors must be in accordance with a certain fire resistance class; 6) penetrations for the wall and ceiling for cable trays must be made of fire-resistant material, and the same applies to ventilation ducts, which must also be closed with approved fire dampers; their activation should be registered by smoke detectors; 7 ) prevent smoke and gases from spreading through ventilation ducts; 8) routing of independent systems, such as pipelines, transport systems, etc. outside the room with electrical equipment (HDI, 2018).

Accordingly, this paper aims to point out the level of efficiency and training of employees in Elektrodistribucija Srbije for fire protection (Beata, Jeffers, \& Kamat, 2018; Gerges, Mayouf, Rumley, \& Moore, 2017; Wei, Zhang, \& Wang, 2018), ie to analyze the manner of implementation of fire protection measures and determine whether these measures are adequately applied. The scientific justification of this paper is reflected in determining the (non) existence of knowledge and readiness of Electricity distribution of Serbia employees on the importance of adequate fire risk management and ways of reacting in case of their manifestation.

\subsection{Literature Review}

Disaster preparedness is a set of actions taken before a disaster occurs, which allows social units to actively react at the time of disaster (McGee \& Russell, 2003). As such, it includes: a) timely and adequate forecasts and warnings; b) education and training of the population; c) establishing an adequate management organization including prepared stocks and established funds to provide support, resource identification, and other activities aimed at improving the safety and efficiency of disaster response (Gillespie \& Streeter, 1987; Gillingham \& Noizet, 2007; Ginige, Amaratunga, \& Haigh, 2009; Rodrigues, Rodrigues, \& da Silva Filho, 2017). It includes activities to develop operational capabilities and facilitate effective disaster response (Godschalk, 1991). On the other hand, fire preparedness is one of the most 
important elements in reducing fire risk and includes community awareness, readiness to provide an appropriate response, and rapid recovery (Kihila, 2017). Thus, it can be pointed out that fire preparedness is defined as planning, equipping, training and practicing, and creating or maintaining capabilities to prevent, mitigate and respond to emergency fire-related activities. The purpose of fire preparedness is to provide an effective response in the event of a disaster (Corrall \& Brewerton, 1999). Numerous researches in foreign and domestic literature (Cvetković \& Janković, 2020; Cvetković et al., 2019; Cvetković, Nikolić, Nenadić, Ocal, \& Zečević, 2020; Cvetković, Roder, Öcal, Tarolli, \& Dragićević, 2018; Cvetković \& Janković, 2021) pointed out that these factors affect the increase or decrease in preparedness to respond to disasters. For example, Cvetković (2017) conducted research to determine the readiness and training of 19 local communities in the territory of the Republic of Serbia to respond to disasters. About 2,500 citizens from 19 local communities participated in this research, and the results showed that the level of training of Serbian citizens to respond to the Armed Forces is at a very low level: only $5.6 \%$ of respondents attended any training to respond to the Armed Forces, and only one third or $34.8 \%$ of respondents are interested in attending such training (Cvetković, 2017).

According to research conducted by Prior and Eriksen (2013), it was pointed out that greater social cohesion among members of the local community contributes to a higher degree of preparedness for fire emergencies (Prior \& Eriksen, 2013). In a 2011 study, when they concluded that a higher level of knowledge and information about disasters is associated with a higher degree of social cohesion in the local community (Eriksen \& Prior, 2011). Glauberman and Cureşti (2018) were engaged in research on fire preparedness in citizens living in high-rise buildings. The results of the research showed that various factors affect the level of readiness of residents to react to fires, and they include the following: perception of fire risk, ownership status (apartment owner or tenant), and readiness for aircraft at the building level. Respondents also pointed out several problems that exist in connection with this topic and gave suggestions on how to keep the residents of high-rise buildings safe during emergency fires (Glauberman \& Qureshi, 2018). Cvetković and Filipović (2018) also examined the perception of the risk of fires in residential buildings. They researched to determine the impact of demographic and socio-economic characteristics on the level of fire risk perception. The results of the conducted research showed that the level of perception of the probability of fire occurrence is the lowest for one year, and then for 5 years, and the highest for 10 years. When it comes to the consequences, most respondents pointed out that a fire could cause them material consequences, then injuries, and finally loss of life (Cvetković and Filipović, 2018a). Cvetković and Gačić (2017) researched to determine the factors that affect the knowledge about the fire in students of 13 high schools in the city of Belgrade. The results of this research indicated that unlike $95.4 \%$ of respondents who point out that they know, only $63.6 \%$ really know what fire is and that only $57.1 \%$ of respondents would react correctly. The results also showed that the perception of students' knowledge of fires is statistically significantly influenced by the following factors: gender, education of father and mother, employment of parents, as well as information through television, the Internet, and video games. Also, it was found that knowledge of the correct way to react to fires is not statistically significantly affected by gender and information on television, while age, education of father and mother and their employment, information via the Internet, video games, and radio (Cvetković and Gacic, 2017 ).

To improve the readiness of everyone to react to disasters caused by fires, and as Cvetković (2020) points out, it is necessary to carry out the following activities: educating citizens to procure fire extinguishers and to carefully study instructions on their use; educating citizens on ways to prevent fires; education on ways to react in case of fire, etc. Preparedness is, therefore, of key importance for successful disaster response, even those caused by fires promoting and maintaining the necessary level of disaster preparedness is the most important prerequisite for improving the safety of citizens (Cvetković, 2020). Therefore, special attention must be paid to this factor, especially when it comes to the power system. 


\section{Methods}

The subject of the research is to examine the level of efficiency of the fire protection system and the training of employees in Elektrodistribucija Srbije for fire protection, ie the analysis of the manner of implementation of fire protection measures, and to determine whether these measures are adequately applied. Following the subject set in this way, the goal of the research was set, and that is the scientific analysis of the manner of application of fire protection measures in Elektrodistribucija Beograd. The aim of the research is primarily descriptive - pointing out the attitudes and opinions of Electricity distribution of Serbia employees in Serbia on the application of fire protection measures and, in this regard, the process of risk management in emergencies caused by fires, but also explicit - determining how gender, age, education, occupation, ie job, affect the readiness and training of persons employed in Elektrodistribucija for adequate response in case of fire. In this way, the research shows, in a comprehensive way, how the fire protection system works in the Electricity Distribution of the Republic of Serbia, ie on the territory of the city of Belgrade. From this it follows: 1) checking the assertion of the connection between demographic characteristics and levels of preparedness, information, knowledge, awareness, existence, and adherence to established procedures, plans, and procedures for fire protection, as well as actions in case of its occurrence; 2) checking the claim of a connection between socio-economic characteristics and levels of preparedness, information, knowledge, awareness, existence, and adherence to established procedures, plans, and procedures for fire protection, as well as actions in case of its occurrence. The only dependent variable is the readiness and training of employees in the electricity distribution company to react in case of fire. This dependency has three dimensions: 1) having knowledge of how to react in case of fire; 2) perception of possible threats and risks related to fire in electricity distribution; 3) attitudes regarding the readiness of the electricity distribution company to adequately manage the risks of fire. Socio-demographic characteristics appear as independent variables: gender, age, level of education, marital status, occupation, and job in the company.

\subsection{Study Area}

Fires can affect various systems and facilities. As one of the very important systems in which fires represent a high source of danger, and primarily due to the basic activity of that system, is the electricity distribution system. The electric power system means a system of natural gas, oil, or oil derivatives consisting of energy facilities interconnected to form a single technical-technological system (Article 2, item 21 of the Energy Law, "Official Gazette of RS, no.154/2014 and 95/2018). The power system is a complex, dynamic system of large dimensions whose primary function is to safely, reliably, and economically supply consumers with sufficient quantities of quality electricity. In Serbia, the most important actors in the electricity sector are the Public Company "Electric Power Industry of Serbia" and the Public Company "Electric Networks of Serbia". The activity of the first-mentioned is energy activity, ie electricity supply. Its main activity is related to: production of electricity and the production of electricity and heat in a combined process; lignite exploitation; electricity distribution and distribution system management; economic entity management; cable telecommunications, etc. (http://Electricity distribution of Serbia.rs/). The public company "Electric Networks of Serbia" is an energy entity that undertakes the following activities: transmission of electricity and management of the transmission system and organization of the electricity market.

\subsection{Socio-economic and demographic characteristics}

The research included a sample of 79 randomly selected respondents, employed in the electricity distribution Belgrade. In relation to gender, out of a total of 79 respondents, most respondents are female, $44(55.70 \%)$ respondents, and male respondents 35 (44.30\%). Respondents included in the research are of 
different ages. The age of the respondents ranges from 25 to 60 years. Considering the different ages of the respondents, and for easier analysis, the data on age is divided into 3 age categories: Category I: respondents aged 25-35; Category II: respondents aged 36-45 years; Category III: respondents aged 46-60 years. Out of the total number of respondents (79), the most respondents belong to Category III (46-60 years), 42 respondents or $53.16 \%$. In second place are respondents who belong to Category II (36-45 years) - a total of 20 respondents or $25.32 \%$. In Category, I (25-35 years) the number of respondents is 17 (21.52\%). Out of the total number of respondents, most of them have completed high school or college. The number of respondents in this category is 49 or $62.03 \%$. This is followed by respondents in category II, ie respondents with completed high school: three-year or four-year: 29 respondents (36.71\%). The respondents are of different occupations, due to a large number of different occupations, a grouping of respondents into categories was not possible The following professions most often appear: graduate economist (11 respondents), graduate electrical engineer (7 respondents), an electrical engineer for sirens and plants (6 respondents), graduate safety manager (4 respondents), electrical engineer (4 respondents), graduate Lawyer (2 respondents), Bachelor of Science in Organizational Sciences (2 respondents), high school graduate (2 respondents) The answers also include: specialist professional economist, radio operator, master engineer of quality and logistics, sales technician, mechanical engineer, trade technician, chemist, master geographer, technical landscape architect, master environmental engineer, etc. Out of the total number of respondents, most are respondents and in category II, ie married/married respondents. Their number is 53 , which is more than half of the respondents or $67.09 \%$. According to the number, the next place is taken by the respondents in the first category, ie unmarried, 19 of them (24.05\%). A total of 6 $(7.59 \%)$ divorced respondents, and only $1(1.27 \%)$ respondents were left without their partner widow/widower (Table 1).

Table 1. Basic socio-economic and demographic information of respondents $(n=79)$.

\begin{tabular}{llcc}
\hline \multicolumn{1}{c}{ Variable } & \multicolumn{1}{c}{ Category } & (f) & $\%$ \\
\hline \multirow{2}{*}{ Gender } & Male & 35 & 44.30 \\
& Female & 44 & 55.70 \\
\multirow{3}{*}{ Age } & $25-35$ & 17 & 21.52 \\
& $36-45$ & 20 & 25.32 \\
\multirow{3}{*}{ Marital status } & $46-60$ & 42 & 53.16 \\
& Single & 19 & 24.05 \\
& Married & 53 & 67.09 \\
& Divorced & 6 & 7.59 \\
\multirow{2}{*}{ Education } & Widow/widower & 1 & 1.27 \\
& Primary Sch. (grade 1-8) & 6 & 5.22 \\
TOTAL & Secondary degree-4 years & 56 & 48.70 \\
& High schooL & 43 & 37.39 \\
& Undergraduate & 10 & 8.70 \\
& & 79 & 100 \\
\hline
\end{tabular}

\subsection{Questionnaire Design}

The structured questionnaire was developed using close-ended and 5-point Likert scale questions (1 strongly disagree to 5 strongly agree). The first part of the questionnaire included the socio-demographic characteristics of the interviewees in Elektrodistribuciji Srbije. Subsequent sections included issues questions related that attitudes regarding the management of risks from disasters caused by fires in the company itself. This questionnaire was created based on the questionnaires used in the research conducted by Kihila (2017) and Cvetković and Filipović (2018). Besides, certain questions from the questionnaire arose as a result of summarizing the findings from numerous other texts and research on this topic. Therefore, 
attitudes regarding the management of risks from emergencies caused by fires in the Belgrade electricity distribution were examined by asking various questions regarding the experience with fires, determining knowledge about how to react, determining the readiness of the company and its equipment for fires, assessment of readiness employee, ie assessment of the company's readiness to react properly in the event of a fire, assessment of the risk of a fire in the company, determining the level of training and desire to acquire new knowledge and skills related to this topic. A pilot pre-test of the questionnaire was conducted in Elektrodistribucija in April 2020 with 10 people to test the comprehensibility and performance of the questionnaire via online systems. Participants provided informed consent to participate in the study. The research protocol was approved by the committees of the Scientific-Professional Society for Disaster Risk Management Board.

\subsection{Analyses}

In this study, descriptive statistics were calculated for the basic socio-economic and demographic characteristics of the participants. The $\chi^{2}$ test analysis (Tabachnick, Fidell, \& Ullman, 2007) was used to examine the relationship between the variables and preparedness scores of the participants. All tests were two-tailed, with a significance level of $p<.05$. Statistical analysis was performed using IBM SPSS Statistics (Version 26). Previous analyses checked on the residual scattering diagram (Tabachnick, Fiddel, \& Ullman, 2007), showed that the assumptions of normality (Normal Probability Plot P-P and Scatterplot), linearity, multicollinearity $(r=.8)$, and homogeneity of variance had not been violated.

\section{Results}

To determine the previous experience of respondents with fires, the question was asked whether they had previously witnessed fires in the company, the largest number of respondents answered in the affirmative $65(82.28 \%)$, while only $14(17.72 \%)$ answered in the negative. The next question was to determine the existence of plans and procedures in the company itself to act in case of fire. To this question, all respondents answered positively, 79 respondents, or 100\%. The table below shows the structure of the answers to this question. To the third question whether the respondents know how to act in case of a fire, almost the majority of respondents answered in the affirmative, ie 66 of them (83.54\%). On the other hand, 12 of them $(15.19 \%)$ are not sure of their knowledge to act correctly in case of fire, and only 1 respondent $(1.27 \%)$ answered in the negative. The next question aimed to support the previous question about the knowledge of the respondents to react properly in case of fire. When asked, respondents were tasked with pointing out one of the ways they would react in the event they spotted a fire. The largest number of respondents, $67(84.81 \%)$ stated that, in this situation, they would call the competent intervention and rescue service. 12 of them (15.19\%) pointed out that, in case they noticed a fire in the company, they would start extinguishing the fire on their own. None of the respondents stated that he would run away in the stated situation, ie "he would not do anything". The next question was to determine whether the Electricity distribution of Serbia company has the appropriate fire-fighting equipment (eg a sufficient number of PP devices). All respondents (100\%) responded positively. Concerning the (non) existence of training conducted with the aim of training employees to react in case of disasters, all respondents answered positively 78 (98.73\%), while only 1 respondent (1.27\%) answered negatively.

The next question was to assess the level of preparedness of the company to respond properly to fire emergencies. Respondents answered the question by rounding the number on a scale from 1 to 5 , where 1 means that the company is "not ready at all", and 5 that it is "completely ready". Following the obtained answers, it was determined that most respondents perceive the readiness of the company as complete, ie they rate it with a grade of "5" - 48 of them (60.76\%). Then, the grade " 4 " - 23 respondents $(29.11 \%)$ and finally "3" - 8 respondents (10.13\%). None of the respondents gave low grades, ie "1" and "2". According to 
the same principle, the respondents assessed their level of readiness to react properly in case of disasters caused by fire. Following the answers, most respondents rated their readiness with a grade of " 5 " - 39 of them $(49.37 \%)$, and then with a grade of " 4 " - 25 of them (31.65\%). 14 respondents, ie $17.72 \%$, assessed their readiness with a grade of " 3 ", and only 1 respondent (1.27\%) gave a grade of "2". None of the respondents thinks that the level of their preparedness can be assessed with a grade of "1" - "I am not ready at all".

Then, the respondents assessed the level of risk of fire in their company (where 1 - there is no such risk, and 5 - risk completely exists). Following the obtained answers, most respondents rated the level of risk with a grade of "4" - 30 of them $(37.97 \%)$, and then with a grade of "5" - 20 of them $(25.32 \%)$. Then follows the grade "3" - 19 respondents (24.05\%), then the grade "2" - 8 respondents (10.13\%) and finally "1" - only 2 respondents (2.53\%). The last two issues concerned the implementation of training and coaching as a factor in raising fire preparedness. This question concerned the respondents' opinion on whether the company should work harder on training employees to respond properly in case of fire (through training, lectures, training). To this question, the vast majority of respondents answered positively 62 (78.48\%). 11 respondents answered negatively, ie $13.92 \%$, and 6 respondents $(7.59 \%)$ were not sure whether the company should do something like that. Finally, on the last question, according to the same principle, the respondents expressed their opinion on whether they would participate in training for reacting in case of fire and thus improve their preparedness. The vast majority of respondents here answered positively 72 $(91.14 \%)$, and only 7 respondents $(8.86 \%)$ answered negatively.

Statistical analysis, comparison, and linking of data on the gender of respondents and data on all attitudes regarding fire risk management and response to aircraft caused by fires in electricity distribution found that there are statistically significant differences on certain issues, and others do not. This means that gender, according to certain attitudes regarding the management of fire risks and reaction in the Armed Forces caused by fires in Electricity distribution of Serbia Belgrade, is a factor that influences. Thus, by comparing the gender of respondents and attitudes regarding the knowledge of how to act in case of fire, there are statistically significant differences: $\chi^{2}=12.37, \mathrm{df}=5.99, p<0.05$. All male respondents positive to this question, while on the other hand, female respondents, answered negative - 1 respondent $(1.27 \%)$, or "I'm not sure" - 12 of them (15.19\%). Related to this is the next question regarding the choice of one of the ways to act in case of fire - when looking at the attitude of respondents regarding the way to act in case of fire in the company and half of the respondents, there are also statistically significant differences: $\chi^{2}=17$, $78, \mathrm{df}=5.99, p<0.05$.

When it comes to the experience with fire in the company Electricity distribution of Serbia, it was found that there are no statistically significant differences between gender and response of respondents: $\chi^{2}$ $=1.13, \mathrm{df}=5.99, p>0.05$. Thus, gender is not a factor influencing whether respondents have had experience with a fire in their company - both women and men have experienced at least one fire situation in the company in which they work. Also, when it comes to the influence of gender on the attitudes of respondents regarding the existence of plans for action in case of fire in the company, there are no statistically significant differences, and given that all respondents answered this question in the affirmative. There are no statistically significant differences between the respondents' claims regarding the existence of appropriate fire response equipment and half of the respondents - all respondents answered positively to this question. As with the question regarding the existence of plans for surrender in case of fire, there was no need to conduct statistical tests, and given that all respondents (both male and female) answered identically.

Furthermore, when it comes to the gender of respondents and their attitudes regarding the (non) existence of training conducted within the company, and with the aim of training on how to react in case of fire, there are no statistically significant differences: $\chi^{2}=0.80, \mathrm{df}=5.99, p>0.05$. There are no statistically significant differences between the sex of the respondents and the assessment of the level of readiness of the company to adequately react in the case of aircraft caused by fires: $\chi^{2}=0.99, \mathrm{df}=9.48, p>0.05$. It is the same with the assessment of the level of preparedness of the employees themselves (personal 
preparedness) to react in case of fire and half of the respondents - there are no statistically significant differences: $\chi^{2}=8.22, \mathrm{df}=9.48, p>0.05$.

When it comes to assessing the level of fire risk in the company and the gender of the respondents, there are no statistically significant differences: $\chi^{2}=9.10 ; \mathrm{df}=9.48 ; p>0.05$. The same is true when it comes to the opinion of the respondents on the need to conduct additional training and coaching of employees to respond properly in case of fire, there are no statistically significant differences: $\chi^{2}=2.08, \mathrm{df}=5.99, p>0.05$. Finally, between the sex of the respondents and their desire to acquire new knowledge in the field of reaction to aircraft caused by fires, and to increase their preparedness, there are statistically significant differences: $\chi^{2}=9.65, \mathrm{df}=5.99, p<0.05$, all-female respondents pointed out that they would attend additional training in this area, while male respondents also include those who don't want to attend additional training.

Observing the age and attitudes of the respondents regarding the management of fire risks and reacting to them, it was found that concerning most questions there are no statistically significant differences (Table 2). On the other hand, between the age of the respondents and their experience of fire in the company, there are statistically significant differences $\chi^{2}=30.94, \mathrm{df}=9.48, p \leq 0.05$. Older respondents point out to a greater extent than younger respondents that a fire could break out. When it comes to the marital status of respondents and their attitudes regarding fire risk management and response in case of their manifestation, it was found that there are no statistically significant differences, ie that it exists only for one attitude and assess the willingness of employees to respond properly. in case of fire $\chi^{2}=28.67, \mathrm{df}=$ $21.02, p \leq 0.05$ (Table 2).

Table 2. Chi-square test results between attitudes and gender, age, and marital status.

\begin{tabular}{|c|c|c|c|c|c|c|c|c|c|}
\hline \multirow[b]{2}{*}{ Variable } & \multicolumn{3}{|c|}{ Gender } & \multicolumn{3}{|c|}{ Age } & \multicolumn{3}{|c|}{ Marital status } \\
\hline & Value & $\begin{array}{l}\text { Sig. (2 - } \\
\text { sided) }\end{array}$ & df & Value & $\begin{array}{l}\text { Sig. }(2- \\
\text { sided })\end{array}$ & $\mathrm{df}$ & Value & $\begin{array}{l}\text { Sig. (2 - } \\
\text { sided) }\end{array}$ & df \\
\hline Fire experience & 1.13 & $p \leq .05^{*}$ & 5.99 & 30.94 & $p \leq .05^{*}$ & 9.48 & 6.35 & $p \geq .05$ & 7.81 \\
\hline Knowledge of fire handling & 12.37 & $p \leq .05^{*}$ & 5.99 & 5.72 & $p \geq .05$ & 9.48 & 7.04 & $p \geq .05$ & 12.59 \\
\hline Choose how to handle a fire & 17.78 & $p \leq .05^{*}$ & 5.99 & 9.45 & $p \geq .05$ & 9.48 & 1.76 & $p \geq .05$ & 7.81 \\
\hline $\begin{array}{l}\text { There are trainings to be } \\
\text { conducted with the aim of } \\
\text { training employees }\end{array}$ & 0.80 & $p \leq .05^{*}$ & 5.99 & 3.69 & $p \geq .05$ & 5.99 & 3.19 & $p \geq .05$ & 7.81 \\
\hline $\begin{array}{l}\text { Evaluation of the } \\
\text { company's preparedness } \\
\text { level to respond properly to } \\
\text { customers }\end{array}$ & 0.99 & $p \leq .05^{*}$ & 9.48 & 20.75 & $p \geq .05$ & 15.50 & 14.05 & $p \geq .05$ & 16.91 \\
\hline $\begin{array}{l}\text { Evaluate the level of } \\
\text { preparedness of employees } \\
\text { to respond properly }\end{array}$ & 8.22 & $p \leq .05^{*}$ & 9.48 & 6.13 & $p \geq .05$ & 15.50 & 28.67 & $p \leq .05^{*}$ & 21.02 \\
\hline $\begin{array}{l}\text { Assess the level of risk of a } \\
\text { fire in the company }\end{array}$ & 9.10 & $p \leq .05^{*}$ & 9.48 & 5.33 & $p \geq .05$ & 15.50 & 8.26 & $p \geq .05$ & 21.02 \\
\hline $\begin{array}{l}\text { The need for the company } \\
\text { to work on additional } \\
\text { training for proper fire } \\
\text { response }\end{array}$ & 2.08 & $p \leq .05^{*}$ & 5.99 & 4.03 & $p \geq .05$ & 9.48 & 1.72 & $p \geq .05$ & 12.59 \\
\hline $\begin{array}{l}\text { The desire of employees to } \\
\text { participate in training }\end{array}$ & 9.65 & $p \leq .05^{*}$ & 5.99 & 3.41 & $p \geq .05$ & 9.48 & 0.76 & $p \geq .05$ & 7.81 \\
\hline
\end{tabular}




\section{Discussion}

Fires in electricity distribution are one of the frequent factors endangering this critical infrastructure (Committee \& Committee, 2004; Hromada \& Lukas, 2012). Given the great importance of the electricity distribution system, its protection from all sources of endangerment, including fire, is of key importance. However, there are few papers dedicated, specifically, to the analysis of the fire risk management process in the electricity distribution, based on a review of existing research, especially in the Republic of Serbia (Cvetković, 2019). Although we have not found in the literature research concerning, in particular, determining the influence of socio-demographic characteristics on attitudes related to employees in electricity distribution, to compare the obtained results we can, in part, use research results used for research purposes. for this master's thesis, ie the research conducted by Kihila (2017) as well as Cvetković and Filipović (2018), and especially when it comes to determining the level of readiness of individuals to react in case of fire.

What is similar to the mentioned research, as well as numerous others, is the fact that certain attitudes are influenced by certain socio-demographic characteristics, ie gender, age, marital status, education, occupation, job, etc (Bojičić, 2013; Cvetković \& Jovanović, 2020). For example, in the research conducted by Cvetković and Filipović, it is realized that the perception of citizens' preparedness is influenced by gender, marital status, employment, and age, without being affected by education. In our research, it was found that only marital status affects the perception of individual preparedness to react in case of fire, while other factors do not. When it comes to the perception of the probability of fire, ie the perception of fire risk, in the above research, the results showed that it is influenced by gender, education, marital status, age, and employment. In the research conducted for this paper, it was found that the perception of fire risk levels is influenced by the level of education. This confirmed the findings of numerous other studies that have shown that belonging to a particular socio-demographic and socio-economic category may have implications for awareness, knowledge, perception, or the opinion and attitudes of individuals about the topic.

Unlike the research conducted by Cvetković and Filipović (2018), which found that citizens rate their fire preparedness at a very low level, our research found the opposite, Electricity distribution of Serbia Belgrade employees believe that they are fully prepared to react, ie their readiness is at the highest level. This result may be a consequence of numerous training and training that take place within the company itself. It is the same with the research conducted by Kihila (2017), where a low level of preparedness, knowledge, and awareness of citizens regarding the reaction in case of fire was also determined. In contrast to these researches, the research conducted for this paper showed that Electricity distribution of Serbia employees has appropriate knowledge about fires, to know how to react properly in case of fires, to adequately perceive risk, to be ready to react in case of fires, as well as to have a high desire to acquire new knowledge and skills in this field. Also, it was determined that the company Electricity distribution of Serbia Belgrade well implements all necessary measures so that the process of fire risk management can be considered effective (implementation of training and education, the existence of established plans and procedures for responding to fires, possession of appropriate equipment, high readiness of the company to react to aircraft fires, etc.).

\section{Conclusions}

The starting point for the preventive action of companies and facilities of the electricity distribution system is to raise the level of knowledge, training, awareness of all (especially employees) to respond properly in case of fire. In this way, the company itself is protected from the dangers and risks of fire. Fires in the electricity distribution are a frequent source of threats, so the question arose as to what and how much 
knowledge employees have about this type of danger, especially in the Republic of Serbia. To establish how the risk of fire in the electricity distribution is perceived, ie to determine the level of readiness of the company to react properly in case of fire, the employees of Electricity distribution of Serbia Belgrade were selected as a sample for the research. The research, which was conducted, aimed to determine the attitudes of employees about the risks of fire, and in this regard, to indicate the knowledge, training, ways, and willingness to react in case of their event (employees and companies). Also, this research was conducted to determine whether there are significant differences between the attitudes of employees regarding fire risk management and response in case of their manifestation and their socio-demographic characteristics.

Certain socio-demographic characteristics also affect certain attitudes, and above all those related to the experience with fire, the knowledge of employees to react in case of fire and the choice of an appropriate response, assessment of the readiness of companies and employees themselves. The experience with fire was found to be influenced by the age and level of education of the respondents; knowledge of how to react in case of fire is influenced by gender and level of education; the choice of one of the methods of action in case of fire is influenced by gender; the assessment of the company's readiness to react properly in the event of a fire is influenced by age; the assessment of the readiness of the employees themselves is influenced by the marital status; the desire of employees to participate in training to increase their preparedness for fires is influenced by gender. As it has been determined, Elektrodistribucija must always respond effectively to all risks, because, otherwise, it would have serious negative implications for the entire social community. Therefore, the system must have appropriate procedures, plans, pre-prepared tasks, activities, and responsibilities for responding to fires, ie it should be fully prepared to respond to all challenges that would arise in the event of an emergency caused by a fire.

Funding: This research was funded by the Scientific-Professional Society for Disaster Risk Management and International Institute for Disaster Research, Belgrade, Serbia.

\section{Acknowledgments}

The authors express their gratitude to the anonymous reviewers for their comments, and the Scientific-Professional Society for Disaster Risk Management (http://upravljanje-rizicima.com/) and International Institute for Disaster Research (http://upravljanje-rizicima.com/medjunarodni-institut-za-istrazivanje-katastrofa/) in Belgrade, Serbia for its scientific and funding support.

Conflicts of Interest: The authors declare no conflict of interest.

\section{References}

1. Aleksandrina, M., Budiarti, D., Yu, Z., Pasha, F., \& Shaw, R. (2019). Governmental Incentivization for SMEs' Engagement in Disaster Resilience in Southeast Asia. International Journal of Disaster Risk Management, 1(1), 32-50.

2. Beata, P. A., Jeffers, A. E., \& Kamat, V. R. (2018). Real-time fire monitoring and visualization for the post-ignition fire state in a building. Fire Technology, 54(4), 995-1027.

3. Bojičić, N. (2013). Funding of the protection and rescue system in the Republic of Serbia. NBP. Nauka, bezbednost, policija, 18(1), 129-143.

4. Cvetković, V. (2017). Informed of citizens about firefighters jurisdiction in emergency situations. Paper presented at the VIII Scientific and professional conference with international participation - Police and judiciary guarantees of freedom and security in a legal state, At Hotel "Omorika" on Tara Mountain, Serbia.

5. Cvetković, V. (2017b). Spremnost građana za reagovanje u prirodnim katastrofama izazvanim poplavama u Republici Srbiji. Vojno delo, 69(1), 153-190. 
6. Cvetković, V. (2019). Risk Perception of Building Fires in Belgrade. International Journal of Disaster Risk Management, 1(1), 81-91.

7. Cvetković, V. M., Ronan, K., Shaw, R., Filipović, M., Mano, R., Gačić, J., \& Jakovljević, V. (2019). Household earthquake preparedness in Serbia: A study of selected municipalities. Acta Geographica, 59(2), 28-42. doi:10.3986/ags.5445

8. Cvetković, V., \& Janković, B. (2021). Private security preparedness for disasters caused by fires. Journal of Criminalistic and Law, NBP, 26(1).

9. Cvetković, V., \& Gačić, J. (2017). Fires as threatening security phenomenon: factors of influence on knowledge about fires. Paper presented at the Conference: 10th International Conference "Crisis management days" - security environment and challenges of crisis management, At 24, 25 and 26 May 2017.

10. Cvetković, V., \& Janković, B. (2020). Private security preparedness for disasters caused by natural and anthropogenic hazards. International Journal of Disaster Risk Management, 2(1), 23-33.

11. Cvetković, V., \& Jovanović, M. (2020). Examination of the factors that influence public perception of mythically-based human behavior in disaster conditions. Glasnik Srpskog geografskog društva, 100(2), 161-179.

12. Cvetkovic, V., \& Martinović, J. (2021). Innovative solutions for flood risk management. International Journal of Disaster Risk Management, 2(2), 71-100. https://doi.org/10.18485/ijdrm.2020.2.2.5

13. Cvetković, V., Giulia, R., Ocal, A., Filipović, M., Janković, B., \& Eric, N. (2018). Children's and youths' knowledge on forest fires: Discrepancies between basic perceptions and reality. Vojno delo, 70(1), $171-$ 185.

14. Cvetković, V., Nikolić, N., Nenadić, R. U., Ocal, A., \& Zečević, M. (2020). Preparedness and Preventive Behaviors for a Pandemic Disaster Caused by COVID-19 in Serbia. International Journal of Environmental Research and Public Health, 17(11), 4124.

15. Cvetković, V., Roder, G., Öcal, A., Tarolli, P., \& Dragićević, S. (2018). The Role of Gender in Preparedness and Response Behaviors towards Flood Risk in Serbia. International Journal of Environmental Research and Public Health, 15(12), 2761. doi:https://doi.org/10.3390/ijerph15122761

16. Fitzgerald, R. W. (2004). Building fire performance analysis (Vol. 79): Wiley Online Library.

17. Fridolf, K., Nilsson, D., \& Frantzich, H. (2013). Fire evacuation in underground transportation systems: a review of accidents and empirical research. Fire Technology, 49(2), 451-475.

18. Gerges, M., Mayouf, M., Rumley, P., \& Moore, D. (2017). Human behavior under fire situations in high-rise residential building. International Journal of Building Pathology and Adaptation.

19. Gillespie, D. F., \& Streeter, C. L. (1987). Conceptualizating and measuring disaster preparedness. International Journal of Mass Emergencies and Disasters, 5(2), 155-176.

20. Gillingham, D., \& Noizet, J. (2007). A response model for the public relations management of a critical incident. Disaster Prevention and Management, 16(4), 545-550. doi:10.1108/09653560710817020

21. Ginige, K., Amaratunga, D., \& Haigh, R. (2009). Mainstreaming gender in disaster reduction: why and how? Disaster Prevention and Management, 18(1), 23-34. doi:10.1108/09653560910938510

22. Glauberman, G., \& Qureshi, K. (2018). Exploratory Qualitative Study of Fire Preparedness Among High-rise Building Residents. PLOS currents, 10.

23. Hasofer, A. M., \& Thomas, I. (2006). Analysis of fatalities and injuries in building fire statistics. Fire Safety Journal, 41(1), 2-14.

24. HDI (2018). Risk engeneering guideline. Fire protection in elektrical equipment rooms. HDI Risk Consulting.

25. HDI. (2018). Risk engeneering guideline. Fire protection in elektrical equipment rooms.: HDI Risk Consulting.

26. Hong-jun, D., \& Xiao-lu, L. (2011). Several Ideas on Fire Detecting Alarm for Power Supply and Distribution System. Procedia Engineering, 11, 75-79.

27. Hromada, M., \& Lukas, L. (2012). Critical Infrastructure Protection and the Evaluation Process. International Journal of Disaster Recovery and Business Continuity, 3. 
28. Hulida, E., Pasnak, I., Koval, O., \& Tryhuba, A. (2019). Determination of the critical time of fire in the building and ensure successful evacuation of people. Periodica Polytechnica Civil Engineering, 63(1), 308316.

29. Jha, D. (2020). Indicator-based assessment of integrated flood vulnerability index for Brunei Darussalam. International Journal of Disaster Risk Management, 2(2).

30. Kasereka, S., Kasoro, N., Kyamakya, K., Goufo, E.-F. D., Chokki, A. P., \& Yengo, M. V. (2018). AgentBased Modelling and Simulation for evacuation of people from a building in case of fire. Procedia Computer Science, 130, 10-17.

31. Kihila, J. (2017). Fire disaster preparadness and situational analysis in higher learning institutions of Tanzania. Jamba- Journal of Disaster Risk Studies, 9(1), a311.

32. Kihila, J. M. (2017). Fire disaster preparedness and situational analysis in higher learning institutions of Tanzania. Jàmbá: Journal of Disaster Risk Studies, 9(1), 1-9.

33. Kobes, M., Helsloot, I., De Vries, B., \& Post, J. G. (2010). Building safety and human behaviour in fire: A literature review. Fire Safety Journal, 45(1), 1-11.

34. Kozlowski, T. T. (2012). Fire and ecosystems: Elsevier.

35. Kuligowski, E. (2013). Predicting human behavior during fires. Fire Technology, 49(1), 101-120.

36. Kumiko, F., \& Shaw, R. (2019). Preparing International Joint Project: Use of Japanese Flood Hazard Map in Bangladesh. International Journal of Disaster Risk Management, 1(1), 62-80.

37. Ma, G., \& Wu, Z. (2020). BIM-based building fire emergency management: Combining building users' behavior decisions. Automation in Construction, 109, 102975.

38. Mano, R., A, K., \& Rapaport, C. (2019). Earthquake preparedness: A Social Media Fit perspective to accessing and disseminating earthquake information. International Journal of Disaster Risk Management, 1(2), 19-31.

39. Mousavi, S., Bagchi, A., \& Kodur, V. K. R. (2008). Review of post-earthquake fire hazard to building structures. Canadian Journal of Civil Engineering, 35(7), 689-698.

40. National Counter-Terrorism Committee. (2003). Critical infrastructure protection in Australia. Trusted Information Sharing Network (for Critical Infrastructure Protection). URL: http://www. cript. gov. au/www/CriptHome. nsf/0/CF33E0FF183F9F56CA256CF6007C220E.

41. Ocal, A. (2019). Natural Disasters in Turkey: Social and Economic Perspective. International Journal of Disaster Risk Management, 1(1), 51-61.

42. Olawuni, P., Olowoporoku, O., \& Daramola, O. (2020). Determinants of Residents' Participation in Disaster Risk Management in Lagos Metropolis Nigeria. International Journal of Disaster Risk Management, 2(2).

43. Pat-Horenczyk, R., Achituv, M., Rubenstein, A. K., Khodabakhsh, A., Brom, D., \& Chemtob, C. (2012). Growing up under fire: Building resilience in young children and parents exposed to ongoing missile attacks. Journal of Child \& Adolescent Trauma, 5(4), 303-314.

44. Prior, T., \& Eriksen, C. (2013). Wildfire preparedness, community cohesion and social-ecological systems. Global environmental change, 23(6), 1575-1586.

45. Rafi, M. M., Wasiuddin, S., \& Siddiqui, S. H. (2012). Assessment of fire hazard in Pakistan. Disaster Prevention and Management, 21(1), 71-84. doi:10.1108/09653561211202719

46. Rodrigues, E. E. C., Rodrigues, J. P. C., \& da Silva Filho, L. C. P. (2017). Comparative study of building fire safety regulations in different Brazilian states. Journal of Building Engineering, 10, 102-108.

47. Tabachnick, B. G., Fidell, L. S., \& Ullman, J. B. (2007). Using Multivariate Statistics (5 th $e d$.$) . Boston, MA:$ Pearson.

48. Thomson, N. (2002). Fire Hayards in Industry. London: Elsievier Science.

49. Vibhas, S., Adu, G. B., Ruiyi, Z., Anwaar, M. A., \& Rajib, S. (2019). Understanding the barriers restraining effective operation of flood early warning systems. International Journal of Disaster Risk Management, 1(2), 1-17. 
50. Wei, Y.-y., Zhang, J.-y., \& Wang, J. (2018). Research on building fire risk fast assessment method based on fuzzy comprehensive evaluation and SVM. Procedia engineering, 211, 1141-1150.

51. Xuesong, G., \& Kapucu, N. (2019). Examining Stakeholder Participation in Social Stability Risk Assessment for Mega Projects using Network Analysis. International Journal of Disaster Risk Management, 1(1), 1-31. 